

\title{
Pengaruh Kompensasi, Disipln Kerja, dan Beban Kerja Terhadap Kinerja Rumah Sakit Aisyiyah Purworejo
}

\author{
Arif Dhermawan', Marynta Putri Pratama ${ }^{2}$ \\ 1Sekolah Tinggi Ilmu Ekonomi Putra Bangsa \\ 2Sekolah Tinggi Ilmu Ekonomi Putra Bangsa \\ Email: ariefdher@gmail.com ${ }^{1}$
}

\section{ARTICLE INFO}

Article History:

Received: July $10^{\text {th }} 2020$

Accepted: July 25th 2020

Published: August 31st 2020

Keywords:

Compensation, Work

Dicipline, Workload,

Performance

\begin{abstract}
Penelitian ini bertujuan untuk menganalisis pengaruh kompensasi, disiplin kerja, dan beban kerja terhadap kinerja perawat Rumah Sakit Aisyiyah Purworejo. Populasi dalam penelitian ini adalah perawat Rumah Sakit Aisyiyah Purworejo dan teknik pengambilan sampel menggunakan sampling jenuh yang berjumlah 40 responden. Teknik pengumpulan data menggunakan kuesioner. Analisis yang digunakan adalah uji validitas, uji reliabilitas, uji asumsi klasik, analisis regresi berganda, dan koefisien determinasi. Alat bantu pengolahan data menggunakan SPSS for windows versi 22.0. Hasil penelitian ini menunjukkan bahwa variabel kompensasi berpengaruh signifikan terhadap kinerja perawat, disiplin kerja berpengaruh signifikan terhadap kinerja perawat, beban kerja berpengaruh signifikan terhadap kinerja perawat Rumah Sakit Aisyiyah Purworejo. Nilai $F_{\text {hitung }}$ sebesar 19,706 lebih besar daripada $\mathrm{F}_{\text {tabel }} 2,86$ dengan tingkat sig 0,000 yang mana lebih kecil dari 0,05 menunjukkan bahwa secara simultan variabel kompensasi, disiplin kerja, dan beban kerja berpengaruh signifikan terhadap kinerja perawat Rumah Sakit Aisyiyah Purworejo.
\end{abstract}

\section{PENDAHULUAN}

Kemajuan teknologi membuat persaingan usaha menjadi lebih ketat. Adanya persaingan perusahaan diharapkan mampu untuk bersaing dengan perusahaan lain. Agar perusahaan mampu berjalan dengan baik, perusahaan harus mampu menyediakan sumber daya yang baik pula. Salah satu faktor utama yang dapat menjadikan keberhasilan perusahaan adalah sumber daya manusia. Untuk mencapai keberhasilan perusahaan, baiknya perusahaan harus mampu mengelola sumber daya manusia secara efektif. Menurut Mathis dan Jackson (2006:3), SDM merupakan suatu rancangan dari berbagai system formal pada sebuah organisasi dengan tujuan memastikan penggunaan dari keahlian manusia secara efektif serta efesien untuk mencapai tujuan organisasi sesuai dengan keinginan. Kinerja karyawan sangat dibutuhkan perusahaan untuk meningkatkan kualitas perusahaan. Menurut Anwar Prabu Mangkunegara (2009:67) mengemukakan bahwa, kinerja adalah hasil kerja secara kualitas dan kuantitas yang telah dicapai oleh seorang pegawai dalam melaksanakan tugasnya sesuai dengan tanggung jawab yang diberikan kepadanya. Apabila perusahaan memiliki sumber 
daya yang berkualitas, maka masalah apa yang dihadapi perusahaan akan dapat diselesaikan secara efektif. Penulis menemukan hasil kinerja perawat di tahun 2017 dan 2018 yang menunjukkan bahwa disana terdapat kinerja yang kurang maksimal. Hasil kinerja perawat dibukukan dengan dikeluarkannya formulir penilaian prestasi kerja. Aspek yang dinilai meliputi aspek teknis pekerjaan yang terdiri dari efektifitas dan efisiensi kerja, ketepatan waktu dalam menyelesaikan tugas, dan kemampuan mencapai target; aspek non teknis yang terdiri dari tertib administrasi, inisiatif, kerjasama dan koordinasi; aspek kepribadian yang terdiri dari perilaku (etika dan moral), kedisiplinan dan kejujuran, tanggung jawab dan loyalitas; dan aspek kepemimpinan yang terdiri dari koordinasi anggota, kontrol anggota, evaluasi dan pembinaan anggota, delegasi tanggung jawab dan wewenang, kecepatan dan ketepatan pengambilan keputusan. Berikut tabel yang menjelaskan sasaran kinerja di 2 tahun yaitu 2017 dan 2018 :

Tabel 1.Sasaran Kinerja Perawat RS Aisyiyah Purworejo 2017

\begin{tabular}{ccccc}
\hline Nilai Mutu & A & B & C & D \\
\hline Bobot & $1140-1500$ & $765-1139$ & $390-764$ & $0-389$ \\
Kualitas & Sangat Baik & Baik & Cukup & Buruk \\
Jumlah & 12 & 17 & 11 & 0 \\
\hline Sumber : RS Aisyiyah Purworejo 2019 & & &
\end{tabular}

Sasaran kinerja perawat Rumah Sakit Aisyiyah dengan tipe penilaian A (76-100), B (51-75), C (26-50), dan D (0-25) dan dengan klasifikasi nilai akhir dengan bobot skor 1140-1500 masuk ke dalam kategori sangat baik, 765-1139 tergolong baik, 390-764 cukup, dan 0-389 masuk ke dalam kategori buruk. Tabel 1 di atas dapat dijelaskan bahwa sasaran kinerja perawat Rumah Sakit Aisyiyah Purworejo pada tahun 2017 di dapat data dengan jumlah predikat nilai A (sangat baik) sebanyak 12 perawat, nilai B (baik) sebanyak 17 perawat, nilai C (cukup) sebanyak 11 perawat dan tidak ada yang mendapatkan perdikat nilai D (buruk).

Tabel 2.Sasaran Kinerja Perawat RS Aisyiyah Purworejo 2018

\begin{tabular}{ccccc}
\hline Nilai Mutu & A & B & C & D \\
\hline Bobot & $1140-1500$ & $765-1139$ & $390-764$ & $0-389$ \\
Kualitas & Sangat Baik & Baik & Cukup & Buruk \\
Jumlah & 10 & 15 & 15 & 0 \\
\hline \multicolumn{2}{l}{ Sumber : RS Aisyiyah Purworejo 2019} & & &
\end{tabular}

Tabel 2 di atas dapat dijelaskan bahwa sasaran kinerja perawat Rumah Sakit Aisyiyah Purworejo pada tahun 2018 di dapat data dengan jumlah predikat nilai A (sangat baik) sebanyak 10 perawat menurun dari tahun sebelumnya yang dengan jumlah 12 perawat yang mendapatkan nilai A, nilai B (baik) sebanyak 15 perawat menurun daripada tahun sebelumnya yang dengan jumlah 17 perawat, nilai $C$ (cukup) sebanyak 15 perawat bertambah banyak daripada di tahun sebelumnya dengan jumlah 11 perawat saja. Presentase kenaikan cukup banyak yaitu $15 \%$ atau naik 4 perawat jika dibandingkan dengan tahun 2017. Nilai tersebut yang didapat perawat berasal dari formulir penilaian kinerja yang dikeluarkan kabid medis. Nilai yang muncul tak lepas dari bagaimana peran dan kinerja perawat terhadap rumah sakit. Item ketepatan waktu dalam menyelsaikan tugas dan disiplin menjadi hal yang harus diperhatikan lebih, karena dalam item tersebut beberapa perawat mendapatkan nilai rendah. 
Dari data wawancara yang didapat, para perawat memberikan keluh kesahnya terhadap kompensasi yang diberikan kepada mereka. Gaji yang dibayarkan perusahaan dibayarkan 2 kali di dalam satu bulan. Hal tersebut terjadi menyusul tagihan klaim dana BPJS yang masih sering terlambat masuk ke dana rumah sakit. Dana klaim BPJS separuh digunakan rumah sakit untuk menunjang kegiatan operasionalnya, termasuk gaji dan insentif karyawan. Kompensasi sangat penting bagi karyawan itu sendiri sebagai individu, karena besarnya kompensasi merupakan ukuran nilai pekerjaan karyawan itu sendiri. Sebaliknya besar kecilnya kompensasi dapat mempengaruhi prestasi kerja, motivasi , kinerja, dan kepuasan kerja karyawan.

Disiplin kerja juga menjadi hal yang utama dalam bekerja. Kebiasaan disiplin yang baik, akan mempermudah seseorang di dalam melakukan sesuatu. Disiplin menjadi sesuatu yang menyebabkan turunnya kinerja perawat, seperti adanya perawat yang datang terlambat ke kantor, bersikap pasif terhadap pekerjaan, tidak tepat dalam menyelesaikan pekerjaannya, dan kurang lengkapnya laporan data status pasien. Keadaan seperti itu berkemungkinan ada sesuatu hal yang dikerjakan atau difokuskan perawat kepada hal lainnya. Keadaan itu dapat menyebabkan efisiensi dan efektifitas kurang bekerja dengan baik. Disiplin merupakan sesuatu yang harus terus dijaga dan ditingkatkan agar perawat terbiasa dengan kedisiplinan penuh dan tanggung jawab sesuai dengan tugas yang diberikan perusahaan.

Selain itu, beberapa juga menyampaikan terdapat beban mental yang mereka hadapi karena harus bertanggung jawab demi keselamatan dan kesehatan pasien. Ditambah dengan keluhan terhadap jam kerja shift perawat yang dibagi dalam waktu yaitu mulai dari jam 21.00 sampai dengan jam 07.00 pagi. Waktu itu dirasa perawat kurang baik terutama untuk hal kesehatan yang berdampak pada keletihan.

Berdasarkan fenomena di atas, penelitian ini mempunyai tujuan yaitu (1) Apakah kompensasi berpengaruh terhadap kinerja perawat RS Aisyiyah Purworejo? (2) Apakah disiplin kerja berpengaruh terhadap kinerja perawat RS Aisyiyah Purworejo? (3) Apakah beban kerja berpengaruh terhadap kinerja perawat RS Aisyiyah Purworejo? (4) Apakah kompensasi, disiplin kerja, dan beban kerja berpengaruh secara bersama terhadap kinerja perawat RS Aisyiyah Purworejo? Hipotesis yang diajukan pada penelitian ini adalah sebagai berikut :

$\mathbf{H}_{1}$ : Kompensasi berpengaruh positif terhadap kinerja perawat RS Aisyiyah Purworejo.

$\mathbf{H}_{2}$ : Disiplin kerja berpengaruh positif terhadap kinerja perawat RS Aisyiyah Purworejo.

$\mathbf{H}_{3}$ : Beban kerja berpengaruh positif terhadap kinerja perawat RS Aisyiyah Purworejo.

$\mathbf{H}_{4}$ : Kompensasi, Disiplin Kerja, dan Beban Kerja secara bersama-sama berpengaruh positif terhadap kinerja perawat RS Aisyiyah Purworejo.

\section{KAJIAN TEORI DAN TELAAH LITERATUR}

Kinerja adalah hasil kerja secara kualitas maupun kuantitas yang dicapai oleh seorang karyawan sesuai dengan tugas dan tanggung jawab dalam suatu periode kerjanya (Mangkunegara, 2004: 9). Menurut Mangkunegara (2011:75) menyebutkan indikator dari kinerja karyawan :
1. Kualitas kerja
2. Kuantitas kerja
3. Pelaksanaan tugas
4. Tanggung jawab 
Menurut Simamora (2006:514) kompensasi adalah bayaran yang diberikan perusahaan untuk dapat meningkatkan produktivitas para karyawan guna mencapai keunggulan yang kompetitif. Indikator-indikator kompensasi menurut Simamora (2004: 445) adalah :

1. Gaji yang adil

2. Insentif yang sesuai

3. Tunjangan yang sesuai dengan harapan

4. Fasilitas yang memadai

Menurut Hasibuan (2004:213) berpendapat bahwa kedisiplinan adalah kesadaran dan kesediaan seseorang menaati semua peraturan perusahaan dan norma-norma sosial yang berlaku. Kemudian indikator disiplin kerja juga dikemukakan oleh Soejono (2000:67) terdapat 4 indikator :

1. Ketepatan waktu

2. Menggunakan peralatan kerja dengan baik

3. Tanggung jawab yang tinggi

4. Ketaatan terhadap aturan kantor

Menurut Munandar (2001:383 ) beban kerja merupakan suatu kondisi dari pekerjaan dengan uraian tugasnya yang harus diselesaikan pada batas waktu tertentu. Xie dan Jons dalam Janssen (2001) mengemukakan bahwa sebuah pekerjaan untuk tuntutan dan kemampuan hubungan tersebut dimoderasi berbentuk melengkung seperti $U$ yang menekankan bahwa orang-orang dengan ruang lingkup tertentu akan mendapatkan kelelahan dan kegelisahan ketika beban yang diberikan perusahaan melebihi batas porsinya. Menurut Sunyoto (2012:64), terdapat indikator-indikator di dalam beban kerja, diantaranya:

1. Target yang harus dicapai

2. Kondisi pekerjaan

3. Penggunaan waktu

4. Standar pekerjaan

\section{METODE PENELITIAN}

Variabel bebas dalam penelitian ini terdiri dari kompensasi, disiplin kerja, dan beban kerja, sedangkan untuk variabel terikatnya adalah kinerja.Populasi dari penelitian ini adalah seluruh perawat Rumah Sakit Aisyiyah Purworejo. Teknik sampel yang digunakan adalah menggunakan sampel jenuh karena jumlah populasi yang relatif kecil yaitu 40 responden. Sugiyono (2013:118) mengemukakan bahwa sampel jenuh adalah teknik penentuan sampel bila semua anggota populasi digunakan sebagai sampel. Pemberian skor pada kuesioner mengacu pada 4 point, yang bermakna: 1 = sangat tidak setuju, $2=$ tidak setuju, $3=$ setuju, 4 = sangat setuju.

Teknik analisis data dalam penelitian ini adalah uji instrumen yang meliputi uji validitas dan uji reliabilitas, uji asumsi klasik yang meliputi uji multikolinieritas, uji heterokedastisitas, dan uji normalitas, analisis regresi linear berganda, uji hipotesis yang meliputi uji partial (uji t) dan uji serentak (uji F), dan koefisien determinasi.

\section{HASIL DAN PEMBAHASAN}

Hasil uji instrumen validitas dan reliabilitas menunjukkan bahwa semua item pengukuran dalam kuisioner dinyatakan valid dan reliabel. Hal ini didasarkan pada hasil uji validitas $r$ hitung untuk semua item pengukuran variabel $>r_{\text {tabel }}=0,3120$ dengan tingkat signifikansi < 
0,05, sedangkan hasil uji instrumen reliabilitas menunjukkan bahwa nilai Alpha Cronbach dari keempat variabel $>0,60$.

Hasil uji multikolinieritas menunjukkan bahwa tidak terjadi gejala multikolinieritas. Hal ini didasarkan pada hasil Collinearity Statistics di bawah ini (tabel 3) yang menunjukkan bahwa nilai Tolerance semua variabel berada di atas 0,10 (10\%) dan nilai VIF semua variabel berada di bawah 10 .

Tabel 3. Nilai Collinierity Statistics

\begin{tabular}{lll}
\hline \multirow{2}{*}{ Variabel } & \multicolumn{2}{c}{ Collinierity Statistics } \\
\cline { 2 - 3 } & Tollerance & VIF \\
\hline Kompensasi (X1) & 0,754 & 1,327 \\
Disiplin Kerja (X2) & 0,927 & 1,079 \\
Beban Kerja (X3) & 0,771 & 1,297 \\
\hline
\end{tabular}

Sumber : Data Primer Diolah 2020

Berdasarkan Gambar 1 dapat diketahui bahwa: (a) titik data penyebar di atas dan di bawah atau di sekitar angka 0, (b) titik-titik tidak mengumpul hanya di atas atau di bawah saja, (c) penyebaran titik-titik data tidak membentuk pola bergelombang melebar kemudian menyempit dan melebar kembali, serta (d) penyebaran titik-titik data tidak berpola. Dengan demikian, dapat diketahui bahwa tidak terjadi masalah heteroskedastistas, sehingga model regresi yang baik dan ideal dapat terpenuhi.

Scatterplot



Sumber : Data Primer Diolah 2020

\section{Gambar 1. Hasil Uji Heteroskedastisitas}

Hasil uji asumsi normalitas menunjukkan bahwa data berdistribusi normal. Hal ini didasarkan pada gambar plot normalitas pada gambar dibawah ini yang menunjukkan bahwa data menyebar di sekitar/mendekati dan mengikuti garis diagonal. 


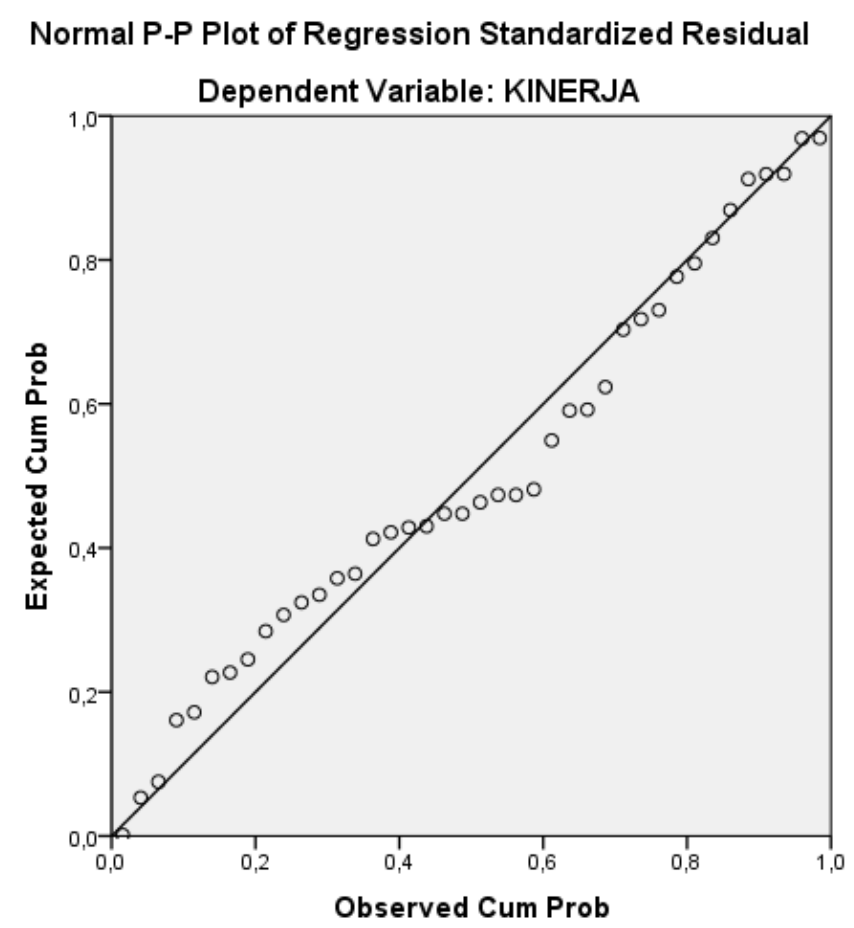

Sumber : Data Primer Diolah 2020

\section{Gambar 2. Hasil Uji Normalitas}

Berdasarkan hasil uji multikolinieritas, heterokesdastisitas, dan normalitas maka dapat dikatakan bahwa tidak terdapat masalah asumsi klasik pada penelitian ini.

Uji $\mathrm{t}$ merupakan satu pengujian individu terhadap variabel bebas $(X)$ dimana untuk mengetahui pengaruh yang signifikan terhadap variabel terikat $(Y)$, yaitu variabel kompensasi $\left(X_{1}\right)$, disiplin kerja $\left(X_{2}\right)$, dan beban kerja $\left(X_{3}\right)$ terhadap kinerja $(Y)$. Dalam pengujian ini ditentukan tingkat signifikan sebesar $5 \%(\alpha=0,05)$ dengan tingkat keyakinan sebesar $95 \%$ $(0,95)$. Untuk mengetahui hasil analisis uji t dalam penelitian ini dapat dilihat sebagai berikut:

Tabel 4. Output Uji t

\begin{tabular}{cccccc}
\hline & $\begin{array}{c}\text { Unstandar } \\
\text { dized B }\end{array}$ & $\begin{array}{c}\text { Coefficients } \\
\text { Std. Error }\end{array}$ & $\begin{array}{c}\text { Standarized } \\
\text { Coefficients } \\
\text { Beta }\end{array}$ & T & Sig \\
\hline (Constant) & $-0,191$ & 2,366 & & $-0,081$ & 0,936 \\
Kompensasi & 0,271 & 0,101 & 0,318 & 2,688 & 0,011 \\
Disiplin Kerja & 0,336 & 0,118 & 0,303 & 2,848 & 0,007 \\
Beban Kerja & 0,424 & 0,112 & 0,44 & 3,771 & 0,001 \\
\hline
\end{tabular}

Sumber : Data Primer Diolah 2020

Pembahasan hipotesis 1: Berdasarkan hasil analisis yang dilakukan, diperoleh nilai sig sebesar 0,011 dan $t_{\text {hitung }}$ sebesar 2,688. Diketahui bahwa dasar pengambilan keputusan Uji t adalah jika nilai sig $<0,05$ atau $t_{\text {hitung }}>t_{\text {tabel }}$ yang berarti hipotesis diterima. Selanjutnya nilai $t_{\text {hitung }}$ dibandingkan dengan nilai $t_{\text {tabel }}$ pada tabel distribusi dengan tingkat kepercayaan $95 \%$ dan 
derajat kebebasan (degree of freedom) sebesar ( $\mathrm{n}-\mathrm{k}$ ) dengan $\mathrm{n}$ banyaknya sampel dan $\mathrm{k}$ banyaknya jumlah variabel, diperoleh $t_{\text {tabel }}$ sebesar 2,026. Hasil yang diperoleh pada uji hipotesis 1 menunjukkan bahwa sig 0,011 <0,05 dan nilai $t_{\text {hitung }} 2,688>t_{\text {tabel }}$ 2,026 dan dapat disimpulkan bahwa hipotesis 1 diterima yang berarti terdapat pengaruh antara Kompensasi (X1) terhadap Kinerja (Y).

Pembahasan hipotesis 2: Berdasarkan hasil analisis yang dilakukan, diperoleh nilai sig sebesar 0,007 dan $t_{\text {hitung }}$ sebesar 2,848. Diketahui bahwa dasar pengambilan keputusan Uji t adalah jika nilai sig $<0,05$ atau $t_{\text {hitung }}>t_{\text {tabel }}$ yang berarti hipotesis diterima. Selanjutnya nilai $t_{\text {hitung }}$ dibandingkan dengan nilai $t_{\text {tabel }}$ pada tabel distribusi dengan tingkat kepercayaan $95 \%$ dan derajat kebebasan (degree of freedom) sebesar ( $\mathrm{n}-\mathrm{k}$ ) dengan $\mathrm{n}$ banyaknya sampel dan $\mathrm{k}$ banyaknya jumlah variabel, diperoleh $t_{\text {tabel }}$ sebesar 2,026.

Hasil yang diperoleh pada uji hipotesis 2 menunjukkan bahwa sig 0,007 $<0,05$ dan nilai $t_{\text {hitung }}$ 2,848 $>t_{\text {tabel }}$ 2,026 dan dapat disimpulkan bahwa hipotesis 2 diterima yang berarti terdapat pengaruh antara Disiplin Kerja (X2) terhadap Kinerja (Y).

Pembahasan hipotesis 3: Berdasarkan hasil analisis yang dilakukan, diperoleh nilai sig sebesar 0,001 dan $t_{\text {hitung }}$ sebesar 3,771. Diketahui bahwa dasar pengambilan keputusan Uji t adalah jika nilai sig $<0,05$ atau $t_{\text {hitung }}>t_{\text {tabel }}$ yang berarti hipotesis diterima. Selanjutnya nilai $t_{\text {hitung }}$ dibandingkan dengan nilai $t_{\text {tabel }}$ pada tabel distribusi dengan tingkat kepercayaan $95 \%$ dan derajat kebebasan (degree of freedom) sebesar ( $\mathrm{n}-\mathrm{k}$ ) dengan $\mathrm{n}$ banyaknya sampel dan $\mathrm{k}$ banyaknya jumlah variabel, diperoleh $t_{\text {tabel }}$ sebesar 2,026.

Hasil yang diperoleh pada uji hipotesis 3 menunjukkan bahwa sig 0,001 <0,05 dan nilai $t_{\text {hitung }}$ 3,771 $>t_{\text {tabel }}$ 2,026 dan dapat disimpulkan bahwa hipotesis 3 diterima yang berarti terdapat pengaruh positif antara Beban Kerja (X3) terhadap Kinerja (Y) dengan asumsi bahwa jika beban kerja yang diberikan melebihi batas porsinya, akan berdampak pada penurunan kinerja.

Pembahasan hipotesis 4: Berdasarkan hasil analisis yang dilakukan diketahui nilai yang dihasilkan dari uji hipotesis serentak adalah sebagai berikut :

Tabel 5. Output Uji Serentak (Uji F)

\begin{tabular}{ccc}
\hline Jumlah Variabel & F & Nilai sig. \\
\hline 4 & 19,706 & 0,000 \\
\hline Sumber : Data Primer Diolah 2020 &
\end{tabular}

Berdasarkan output di atas diketahui nilai sig untuk pengaruh Kompensasi (X1), Disiplin Kerja (X2), dan Beban Kerja (X3) secara simultan terhadap Kinerja (Y) adalah sebesar 0,000 < 0,05 dan nilai $\mathrm{f}_{\text {hitung }} 19,706>\mathrm{f}_{\text {tabel }} 2,86$, sehingga dapat disimpulkan bahwa Hipotesis 4 diterima yang berarti terdapat pengaruh secara simultan antara Kompensasi (X1), Disiplin Kerja (X2), dan Beban Kerja (X3) terhadap Kinerja (Y).

Koefisien determinasi $\left(\mathrm{R}^{2}\right)$ digunakan untuk mengetahui berapa persen pengaruh yang diberikan variabel independent (Kompensasi, Disiplin Kerja, dan Beban Kerja) secara simultan terhadap Kinerja $(Y)$.

Tabel 6. Output Koefisien Determinasi $\left(\mathbf{R}^{2}\right)$

\begin{tabular}{ccc}
\hline $\mathrm{R}$ & $\mathrm{R}$ Square & Adjusted R Square \\
\hline 0,788 & 0,622 & 0,59 \\
\hline Sumber : Data Primer Diolah 2020 &
\end{tabular}


Berdasarkan output di atas diketahui nilai $\mathrm{R}$ square sebesar 0,622, dapat diartikan bahwa Kompensasi (X1), Disiplin Kerja (X2), dan Beban Kerja (X3) mempunyai pengaruh secara simultan terhadap Kinerja (Y) sebesar 62,2 \%, sedangkan sisanya 37,8 \% dipengaruhi oleh variabel lain yang tidak diteliti.

\section{Penutup dan Saran}

Berdasarkan hasil dan pembahasan, penelitian ini dapat disimpulkan sebagai berikut:

1. Kompensasi mempunyai pengaruh positif terhadap kinerja perawat Rumah Sakit Aisyiyah Purworejo. Dapat diartikan jika kompensasi yang diberikan perusahaan baik, maka kinerja yang dihasilkan perawat akan baik.

2. Disiplin kerja mempunyai pengaruh positif terhadap kinerja perawat Rumah Sakit Aisyiyah Purworejo. Dapat diartikan jika disiplin yang diterapkan perawat baik, maka kinerja yang dihasilkan akan baik.

3. Beban kerja mempunyai pengaruh positif terhadap kinerja perawat Rumah Sakit Aisyiyah Purworejo. Dapat diartikan jika beban kerja yang diberikan perusahaan sesuai porsinya akan berdampak baik pada kinerja perawat, sebaliknya jika beban kerja yang diberikan terlalu banyak, akan menyebabkan menurunnya kinerja.

4. Kompensasi, disiplin kerja, dan beban kerja mempunyai pengaruh positif dan signifikan terhadap kinerja perawat Rumah Sakit Aisyiyah Purworejo secara bersamasama.

Berdasarkan hasil penelitian, saran yang dapat diberikan kepada perusahaan:

a. Perusahaan diharapkan dapat memperhatikan ketepatan waktu dalam pembayaran kompensasi, karena dalam hasil penelitian menunjukkan bahwa kompensasi mempunyai pengaruh yang paling besar terhadap kinerja perawat.

b. Perusahaan diharapkan mampu meningkatkan kedisiplinan khususnya untuk perawat dengan lebih menekankan absensi, dan juga pengontrolan rutin terhadap apa yang sudah dikerjakan perawat untuk setiap harinya. Disiplin seperti itu perlu ditingkatkan, karena dalam hasil penelitian menunjukkan bahwa disiplin kerja berpengaruh terhadap kinerja perawat.

c. Perusahaan diharapkan mampu menyesuaikan beban kerja yang diberikan kepada perawat sesuai dengan job deskripsinya atau sesuai dengan porsinya. Berdasarkan hasil penelitian menunjukkan bahwa beban kerja berpengaruh positif terhadap kinerja, itu berarti jika beban kerja yang diberikan perusahaan sesuai porsinya akan berdampak baik pada kinerja perawat itu sendiri. Sebaliknya, jika beban kerja yang diberikan perusahaan terlalu banyak atau melebihi porsi, itu akan menyebabkan perawat menjadi kelelahan dan nantinya akan berdampak buruk pada kinerja mereka.

\section{Referenasi}

Arikunto, S. (2016). Prosedur Penelitian: Suatu Pendekatan Praktik. Jakarta: Rineka Cipta.

Danang, S. (2012). Manajemen Sumber Daya Manusia. Jakarta: PT Buku Seru.

Ghozali, I. (2009). Aplikasi Analisis Multivariate dengan Program SPSS. Semarang: Universitas Diponegoro.

Hasibuan, M. (2004). Manajemen, Edisi Revisi. Jakarta : PT Bumi Aksara. 
Hasibuan, M. (2002). Manajemen Sumber Daya Manusia. Jakarta: Bumi Aksara.

Janssen, O. (2001). Fairness perceptions as a moderator in the curvilinear relationships between job demands, and job performance and job satisfaction. Academy of management journal, 44(5), 1039-1050.

Mangkunegara. (2009). Manajemen Sumber Daya Manusia. Bandung: PT Remaja Rosdakarya.

Mangkunegara. (2011). Sumber Daya Manusia Perusahaan. Bandung: Remaja Rosdakarya.

Mangkunegara. (2015). Sumber Daya Manusia Perusahaan. Cetakan Kedua Belas. Bandung: Remaja Rosdakarya.

Mathis, R.L., \& Jackson. J.H. (2006). Manajemen Sumber Daya Manusia. Jakarta: Salemba Empat.

Munandar. (2001). Stress dan Keselamatan Kerja. Jakarta: UI.

Simamora, H. (2006). Manajemen Sumber Daya Manusia. Yogyakarta: Sekolah Tinggi Ilmu Ekonomi YKPN.

Sugiyono. 2013. Metodelogi Penelitian Kuantitatif, Kualitatif dan R \& D. Bandung.: CV Alfabeta. 